\title{
31. BASEMENT ROCKS OF THE SOUTH-CENTRAL ROSS SEA, SITE 270, DSDP LEG 28
}

\author{
A.B. Ford, U.S. Geological Survey, Menlo Park, California \\ and \\ Peter J. Barrett, Victoria University of Wellington, Wellington, New Zealand
}

\begin{abstract}
Calcareous metamorphic rocks of a continental-type crystalline basement were recovered by drilling at Site 270 in the south-central Ross Sea. Calcareous basement gneiss is of amphibolite-facies metamorphic rank and may correlate with calcareous metasedimentary rocks of similar rank in the early Paleozoic(?) Skelton Group near McMurdo Sound. The basement rocks are overlain by 25 meters of coarse, angular, poorly sorted sedimentary breccia, the upper 3 meters of which is a deeply weathered regolith. The regolith is overlain unconformably by a thick sequence of mainly glaciomarine sediments of Oligocene and younger age.

The breccia is interpreted as a probable talus or solifluction deposit derived from a nearby topographic high of basement rocks. Abundant fragments of marble and calc-silicate gneiss similar to the cored basement rocks, and numerous fragments of highly varied granitic and other metamorphic rocks in the breccia indicate that the basement terrane near Site 270 is a granitic and metamorphic complex probably similar to that of coastal parts of south Victoria Land near McMurdo Sound. Sedimentary rocks similar to those of the Devonian to Jurassic Beacon Supergroup and mafic-igneous rocks similar to those of the Jurassic Ferrar Dolerite were not observed in the breccia, suggesting that these widespread Victoria Land units do not extend to this region.
\end{abstract}

\section{INTRODUCTION}

The Ross Sea and its extension southward beneath the Ross ice shelf forms one of two opposing great embayments into the otherwise almost circular plan of Antarctica. Ever since the Ross Sea was first explored, from the mid 1800's to early 1900's, it has been the subject of geological controversy. Early speculation of an immense crustal depression-the "senkungsfeld" concept of T.W. Edgeworth David and R.E. Priestley of the 19071909 British Nimrod expedition-connecting the Ross Sea and Weddell Sea embayments, and separating east and west Antarctica, has persisted in various modifications to the present time. One of the major objectives of drilling at Site 270 of the Deep Sea Drilling Project was to sample basement rocks of the central part of Ross Sea in order to determine geological characteristics of this antarctic continental-shelf region and to test various interpretations of the tectonic framework that have been proposed for this part of Antarctica. In this preliminary report we briefly describe and interpret the core recovered from the basal units at Site 270.

\section{LOCATION AND GENERAL SETTING}

Site 270 is located in the south-central Ross Sea at lat $77^{\circ} 26.48^{\prime} \mathrm{S}$, long $178^{\circ} 30.19^{\prime} \mathrm{W}$. The site is about $100 \mathrm{~km}$ from the front of Ross ice shelf and approximately 450 $\mathrm{km}$ from the coast of Victoria Land (Figure 1). The site is located on the continental shelf, in a water depth of 634 meters. A north-northeast-trending ridge at the site corresponds with a basement high that separates a region of considerable relief in the western Ross Sea from one of lower relief in the eastern Ross Sea (Hayes and Davey, this volume). A small outcrop area of basement rock on the sea floor, inferred from seismic profiler data of Houtz and Davey (1973), lies just west of the site. The Ross Sea profiler records show that sedimentary rocks overlying the basement are gently folded about generally north-trending axes. The fold trends are highly discordant to northwest-trending fold axes of basement rocks exposed in northern Victoria Land and in Marie Byrd Land. The broadly folded sedimentary rocks indicated in the profiler records were cored at Sites 270-273 in the central and western parts of Ross Sea and were found to be a largely glacial sedimentary sequence ranging in age from Oligocene to Holocene.

\section{OCCURRENCE AND AGE}

Calc-silicate gneiss, schist, and impure marble are the oldest rocks recovered at Site 270 . These rocks are part of a crystalline basement that was only superficially sampled. The basement terrane was cored for about 10 meters, but only $25 \%$ of this was recovered. The base- 


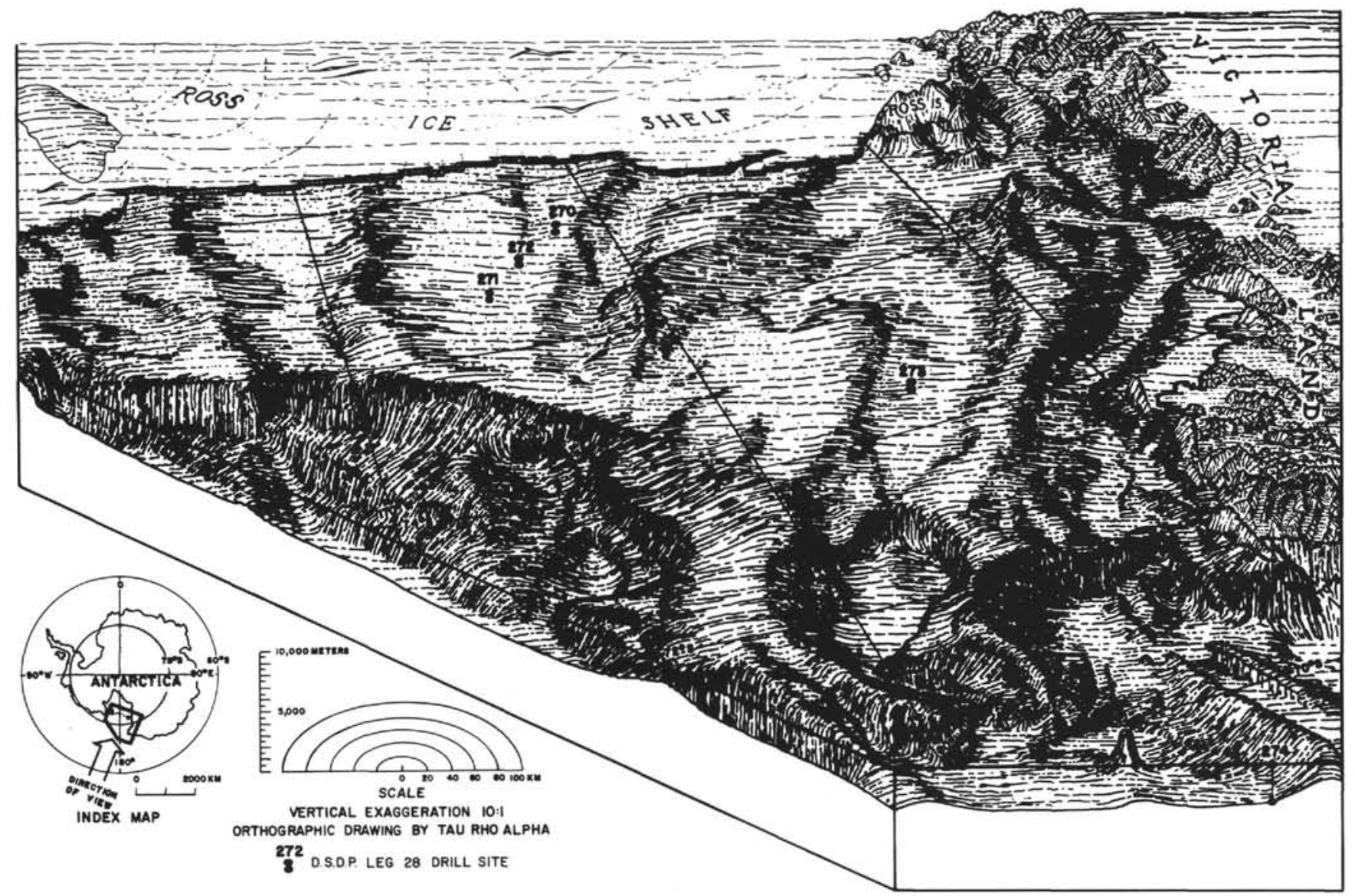

\section{ROSS SEA CONTINENTAL SHELF \\ U S GEOLOGICAL SURVEY}

Figure 1. Index map of Ross Sea showing location of Site 270. Physiographic diagram by Tau Rho Alpha.

ment rocks are overlain by about 25 meters of sedimentary breccia whose coarse, angular, and little-sorted nature and great lithologic variety of fragments give it a chaotic appearance. The upper 3 meters of the breccia is an intensely altered regolith which is overlain by a mostly glaciomarine Cenozoic sedimentary sequence about 386 meters thick (Figure 2). At the base of this sequence are two thin, nonglacial units, a carbonaceous sandstone, 0.7 meter thick, and an overlying calcareous greensand, 0.8 meter thick.

The glaciomarine rocks above the greensand range in age from Holocene to Oligocene (see Site 270 paleontology report, this volume). Paleomagnetic stratigraphy for Site 270 indicates an age of about 25 m.y. for the oldest glaciomarine rocks (Allis et al., this volume), and $\mathrm{K}-\mathrm{Ar}$ dating of glauconite from the greensand has yielded a minimum age of 26.0 m.y. (McDougall, this volume). The basement rocks and breccia can thus be dated only as Oligocene or older as no means has been found for dating them directly or for indicating a maximum age limit. A possible early Paleozoic or older age for the basement rocks may be inferred on lithologic grounds if they correlate with calcareous metasedimentary rocks of the Skelton Group of southern Victoria Land near McMurdo Sound (Blank et al., 1963).

\section{BASEMENT ROCKS}

\section{Lithology and Structure}

Basement materials cored at Site 270 are mostly impure calcareousmetasedimentary rocks. The upper part of the unit, in Cores 47 and $48^{1}$, is layered marble, mostly dark greenish-gray (wet surface) or light bluish-gray (dry surface), with from $10 \%$ to $20 \%$ thin layers and lenses, commonly $5-10 \mathrm{~mm}$ but as much as $50 \mathrm{~mm}$ thick, of medium gray to white, fine- to coarse-grained marble. The lower part of the basement unit, in Core 49, consists of calc-silicate gneiss with interlayered medium gray and grayish-olive to moderate brown rock. A few thin interlayers of calc-silicate schist occur within the marble.

Many rocks are conspicuously layered (Figures 3 and 4). Foliation is locally pronounced in chlorite-rich layers which are mainly in the calc-silicate gneiss. Layering and foliation are subhorizontal throughout the basement cores. Locally the layering shows small-scale warps,

\footnotetext{
'Method of labeling cores and sections of cores given in Laughton, Berggren, et al. (1972).
} 


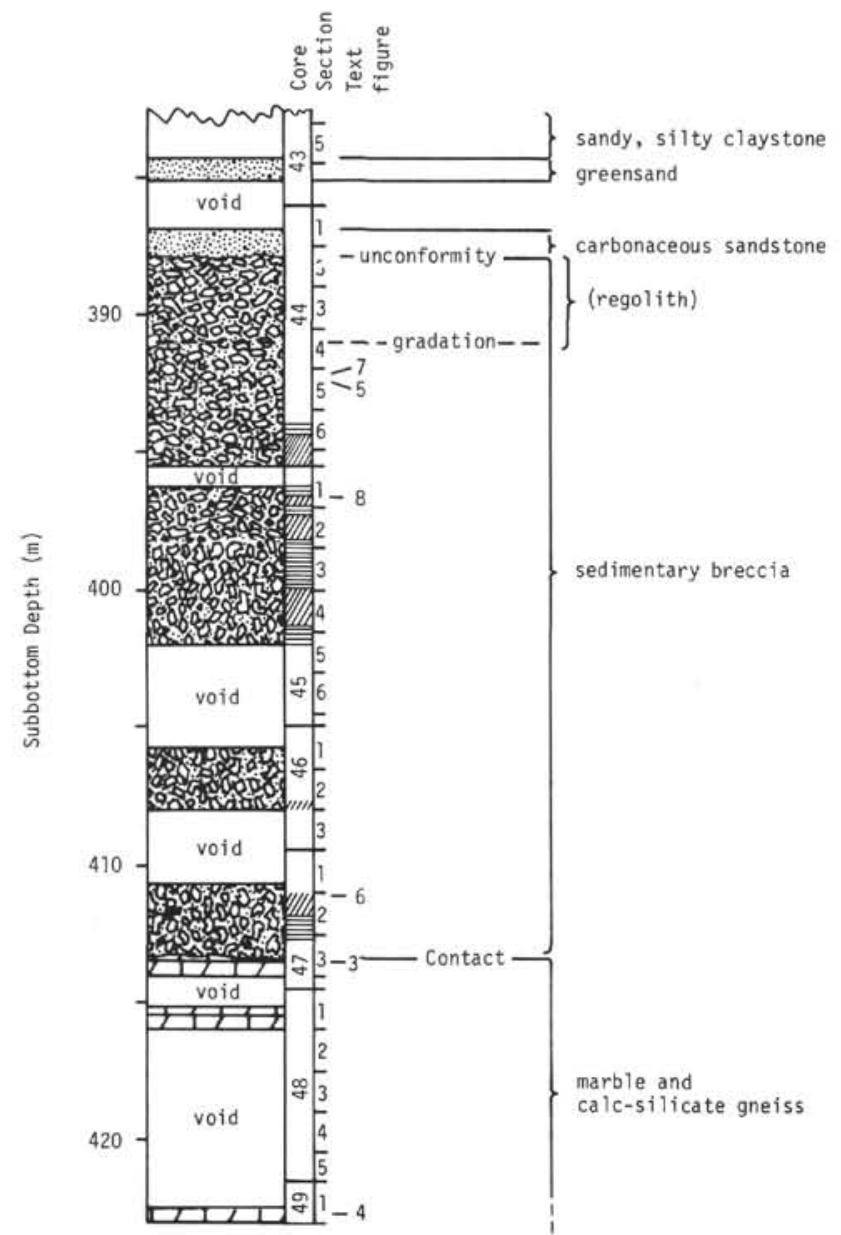

Figure 2. Generalized columnar section of basal units at Site 270, showing stratigraphic location of photograph figures illustrating rock characteristics. Tick marks on core column represent section boundaries, and lined areas indicate parts of column in breccia unit showing horizontal or inclined bedding.

with amplitudes of $1-2 \mathrm{~cm}$, as seen in the mid part of Figure 3b. Layered structure in the marble is chiefly defined by color and grain-size differences, and in the calc-silicate gneiss by color and compositional differences.

The marble is generally weakly brecciated and in places strongly sheared. Effects of brecciation are greater in the upper part of the marble than in the lower, and are absent in underlying calc-silicate gneiss. As seen in Figure 3, many small blocks $1-3 \mathrm{~cm}$ across have been dislocated and rotated; layers have been fractured and sheared into lensoid shapes; and in several subhorizontal zones, $1-2 \mathrm{~cm}$ thick, crushing has entirely destroyed original layering. At several places, as in the lower part of Figure 3a, darker fine crush material appears to have been injected as tongues and veinlets into layered marble. Throughout the upper part, the marble is cut by a branching network of similar dark veinlets 1-2 mm thick. These veinlets also occur lower in the marble but are less abundant. Only a few veinlets cut the calc-silicate gneiss. Most veinlets are vertical or subhorizontal; others cut the marble irregularly. Offsets of up to several millimeters of marble laminae across the
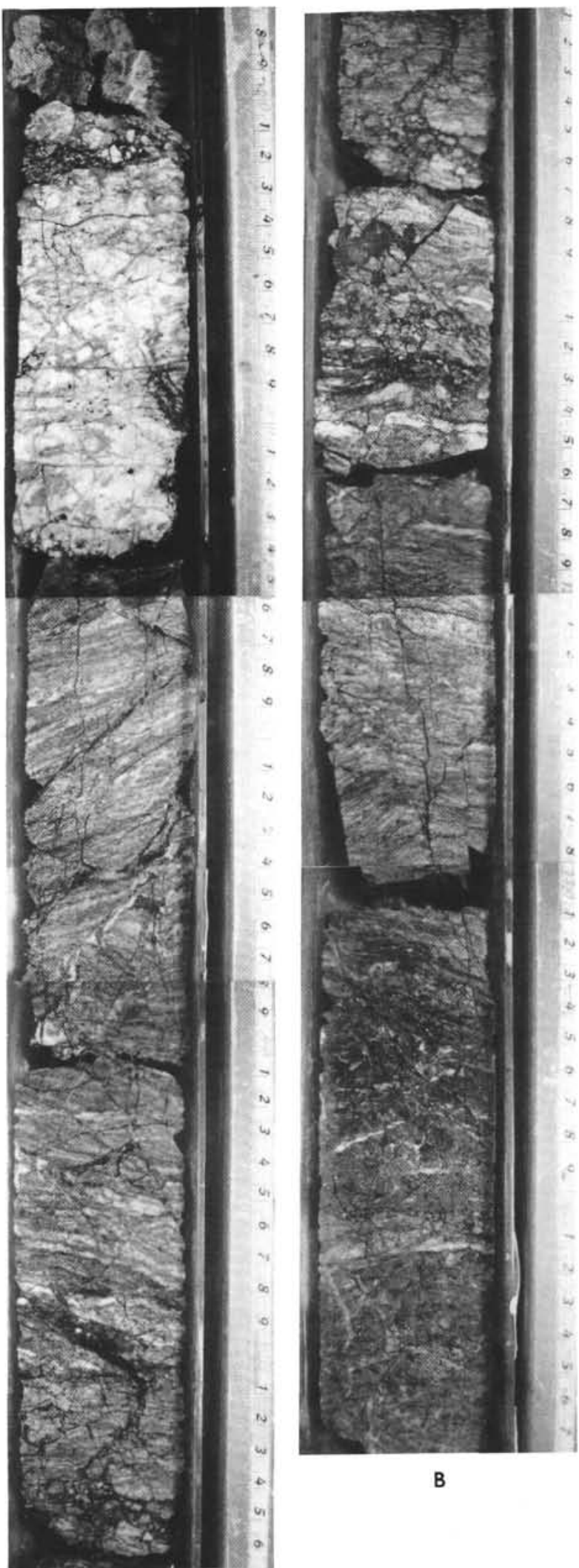

B

\section{A}

Figure 3. Layered marble of upper part of basement unit, Core 47, Site 270. Scale in centimeters. Large white rock of 15-cm long core piece near top of $\mathrm{A}$ is altered granite an apparent breccia clast, below which is contact with basement rocks. Section seen in B overlaps about $6 \mathrm{~cm}$ with lower part of $\mathbf{A}$. 


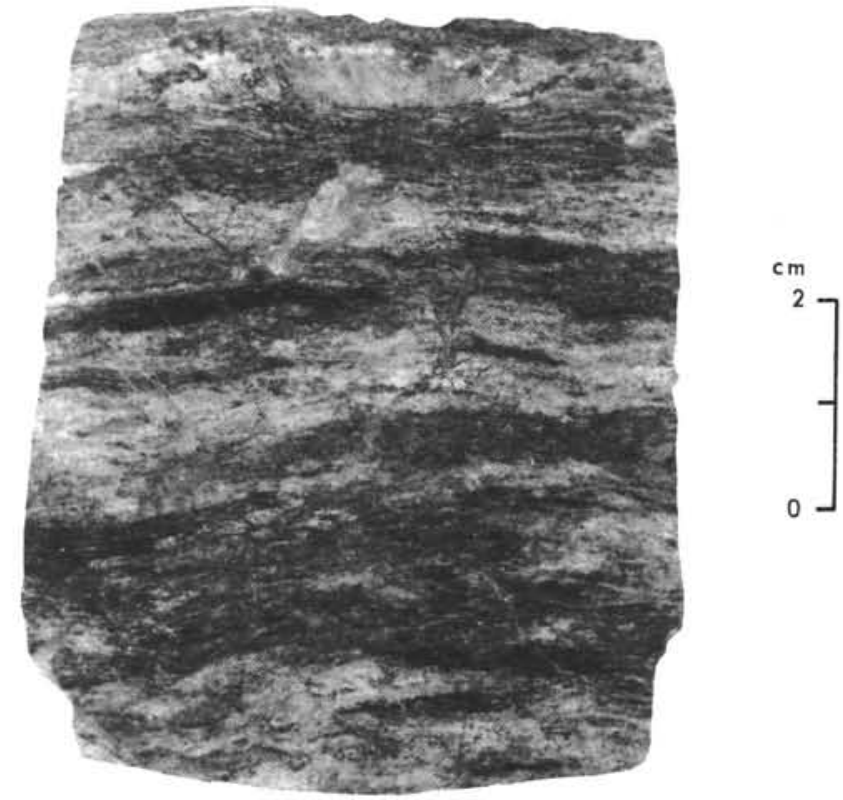

Figure 4. Calc-silicate gneiss from $35 \mathrm{~cm}$ above base of Site 270.

veinlets are common, indicating that the veinlets accompanied or followed microshearing.

\section{Petrography and Interpretation}

The metamorphic rock at the base of the hole (Figure 4 ), in Core 49 , is compositionally layered calc-silicate gneiss. Lighter colored quartz- and calcite-rich layers, 5$10 \mathrm{~mm}$ thick, alternate with darker colored layers of graphitic chlorite schist, $5-20 \mathrm{~mm}$ thick. Xenoblastic diopside and clinozoisite are common constituents of both types of layers and are associated locally with rare wollastonite(?). K-feldspar and altered plagioclase(?) are present locally, mainly in the quartz-calcite layers. Sphene, commonly idioblastic, is the major accessory mineral, and apatite is minor. Biotite is mostly altered to chlorite. The quartz-carbonate layers have general granoblastic fabric, contrasting with the highly schistose fabric of chlorite-rich layers. Post-crystalline deformation is indicated by local distruption and bending of crystals and, in quartz, by common undulatory extinction. Coarsely granoblastic and polygonal carbonate, in patches as large as 1-2 cm across, has developed by posttectonic recrystallization. The gneiss is pervasively altered and is cut by a few thin veinlets, 1-2 mm thick, of iron oxide, carbonate, chlorite, and zeolite.

Textures and mineral assemblages clearly show several stages of metamorphism. The presence of diopside indicates a metamorphic grade of at least amphibolite facies (Turner, 1968). Effects of retrogressive metamorphic recrystallization and alteration in the greenschist facies are widely superimposed on the amphibolite-facies assemblage. The latest alterations, apparently associated with veining, occurred in the zeolite facies.

\section{SEDIMENTARY BRECCIA}

\section{General Comments}

The basal unit of marble and calc-silicate gneiss is overlain by chaotic-appearing sedimentary breccia composed of poorly sorted silt- to boulder-size crystallinerock fragments cemented chiefly by calcite. Although the deposit itself is not part of the basement terrane, the fragments within it were probably derived from a nearby topographic high and they therefore provide a sample of the basement rocks in the general area. As few thin sections were available for this study, most rock identifications given below are based on megascopic studies made onboard the ship.

\section{Contact Relations and Regolith}

The sharp contact of the breccia with the overlying sedimentary sequence is an unconformity. As the age of the breccia is unknown, the time span represented by the unconformity is also unknown. The upper 3 meters of breccia was intensely altered, probably by weathering, before deposition of carbonaceous sand in the Oligocene.

The upper 3 meters of intensely altered rock is believed to be a buried regolith, but it is unknown how much, if any, of the alteration resulted from sea-floor weathering (halmyrolysis) during possibly slow sedimentation of carbonaceous and glauconitic sands and how much resulted from subaerial weathering. Intensity of alteration decreases downward. Except for fragments of probable vein quartz, all clasts in the upper one-third of the weathered zone are so highly altered that original lithologies are obscured. A few pods and veinlets of white carbonate conspicuously cut the sandto clay-size matrix of chloritic and argillic material which is generally greenish-gray to dark greenish-gray in color. The matrix and many clasts in the regolith are highly firable. The transition, at about 3 meters, from regolith to underlying breccia is gradational over tens of centimeters, and is arbitrarily placed at the level where the matrix is sufficiently cohesive to allow core breakage into large blocks. Much of the breccia below this level, however, is also altered.

The exact location of the basal contact of the breccia deposit is not certain. As the lower part of the deposit contains numerous large fragments of veined and brecciated marble and calc-silicate rock closely similar to the basement rock described above, the contact is arbitrarily placed at the level where layering in marble becomes generally uniform in orientation and beiow the lowest probable clast. The contact is, therefore, believed to be at the base of a large, white, altered and sheared granitic rock (near top, Figure 3a), which is interpreted as a large clast. The contact location is uncertain, however, as the granitic rock could conceivably represent a dike, and the irregularly oriented marble fragments extending to about $50 \mathrm{~cm}$ above the inferred contact could represent more highly brecciated basement rock that is essentially in place. There is no evidence of a weathered zone at the basal contact. 


\section{Lithology and Structure}

The breccia is characterized by a complete lack of sorting over most of its thickness (Figure 5). Rock fragments of sand to boulder size, ranging from a few millimeters to $50 \mathrm{~cm}$ in apparent length, form $50 \%$ to $70 \%$ of the deposit. They are mostly subangular but vary from angular to subround. The poor sorting, angularity, and wide range of lithology of fragments give the rock a chaotic appearance.

Several sandy intervals, from 1 to $20 \mathrm{~cm}$ thick, free of lithic clasts larger than a few millimeters provide the clearest indication of local bedding in the breccia deposit (Figures 6-8). Contacts between sandy layers and breccia seem to be gradational over several centimeters (Figure 7). Bedding fabric in the breccia may be indicated by preferred alignment of elongate clasts in the core, but such fabric is rarely as well developed as seen in Figure 6. Oriented-clast fabric, where seen, and apparent bedding vary in dip from subhorizontal to $20^{\circ}$. $30^{\circ}$ in different layers. The deposit as a whole seems therefore to be made up of alternating subhorizontal and dipping layers of widely varying thickness.

The breccia matrix in general, and many clasts, are greenish-gray when wet, or pale olive when dry. However, six intervals from 1 to $30 \mathrm{~cm}$ thick show distinctive grayish-red to grayish-brown colors, suggesting oxidation. Three are thin sandy intervals in Core 44, Section 5 (Figure 7) and Core 45, Section 2, and three are $10-$ to $30-\mathrm{cm}$ thick intervals in breccia in Core 46 , Section 2. The grayish-red or brown rock generally grades through 1 or $2 \mathrm{~cm}$ into the more typical greenishgray rock.

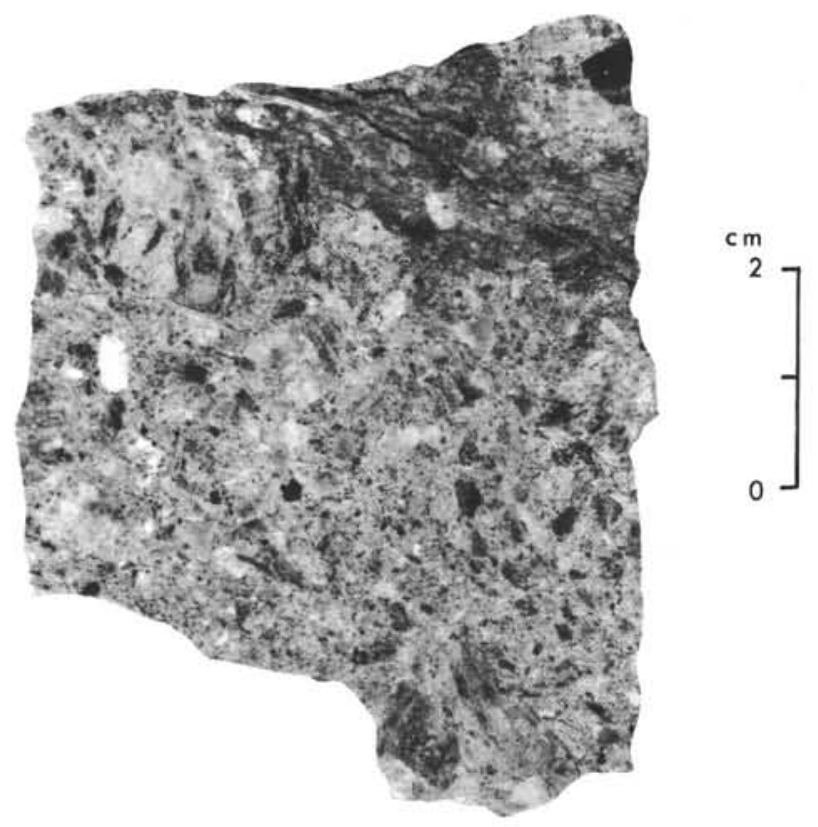

Figure 5. Unsorted sedimentary breccia from Core 44, Site 270 , at a subbottom depth of 392.4 meters. General color of rock is pale olive except for 1-cm-thick darker layer near top which is brownish gray. The general texture seen here though finer grained is characteristic of most of the breccia deposit.
Clasts vary widely in lithology. In the lower twothirds of the regolith the clasts are very strongly altered, but megascopically recognizable lithologies include granite, fine-grained leucogranite or aplite, granitic gneiss, pink-garnet-bearing quartzofeldspathic gneiss, white vein quartz, calc-silicate gneiss(?), and rare dark argillite or hornfels. Most primary mafic minerals in these rocks have been completely destroyed by weathering. Generally similar clast lithologies are identified in the less-altered breccia below the regolith. Many of the clasts, however, are altered, and many appear to be strongly sheared. Where the matrix is little altered, the shear planes are seen to be confined to the clasts. In addition to those above, clast lithologies below the regolith

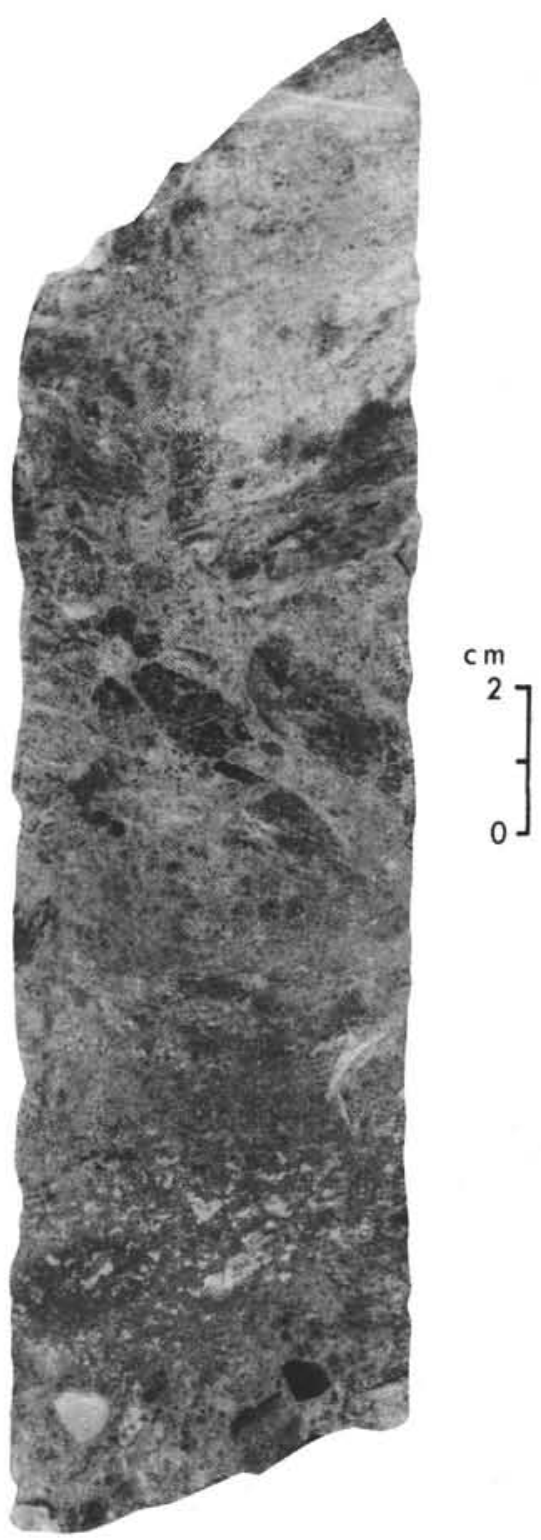

Figure 6. Poorly sorted sedimentary breccia from Core 47, Site 270, at a subbottom depth of 411.2 meters, showing local alignment of large clasts in sandy matrix. General color of rock is dusky yellow-green. 


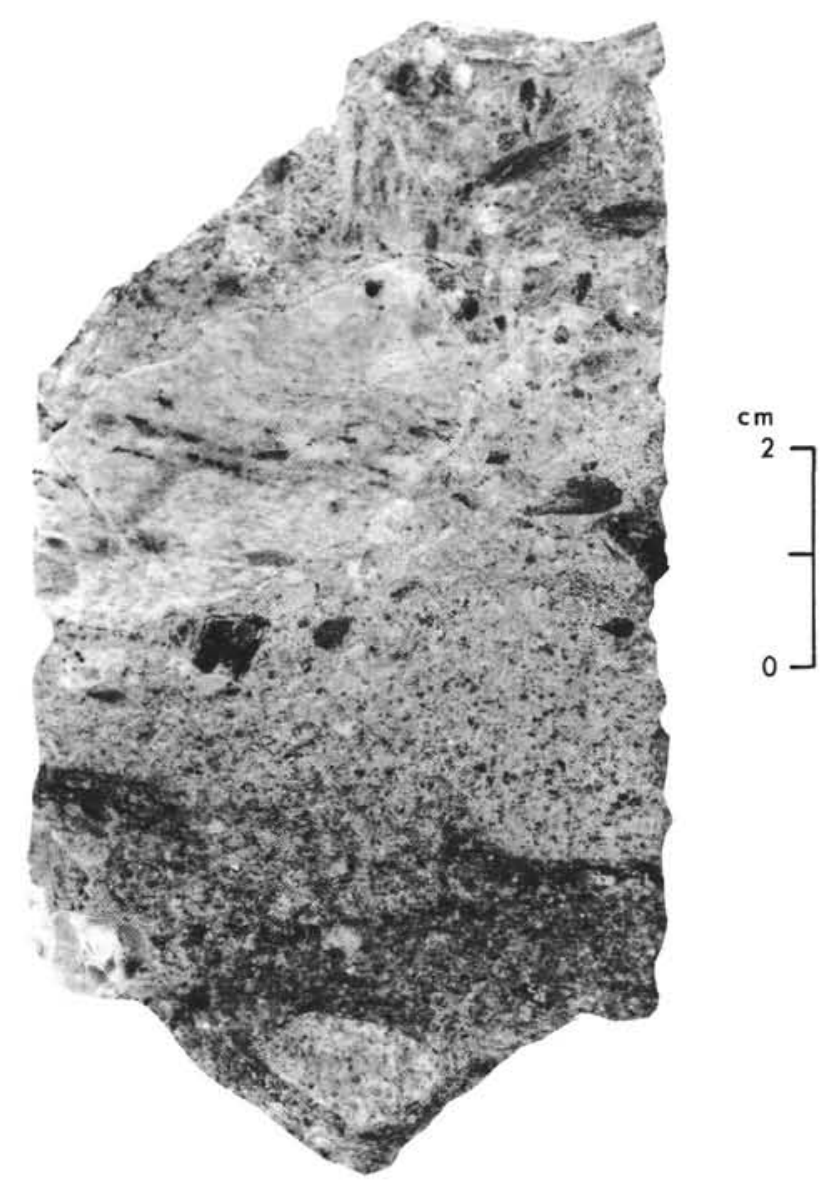

Figure 7. Sandy layer gradational into breccia, Core 44, Site 270, at a subbottom depth of 392.1 meters. Large clast, about $4 \mathrm{~cm}$ long, in upper left is foliated leucogranite, and $1 \mathrm{-cm}$ long clast, lower center, is nonfoliated granite. General color of lighter sandy portion of core is moderate greenish-yellow to grayish-yellow-green, and of darker portion below is grayish-brown.

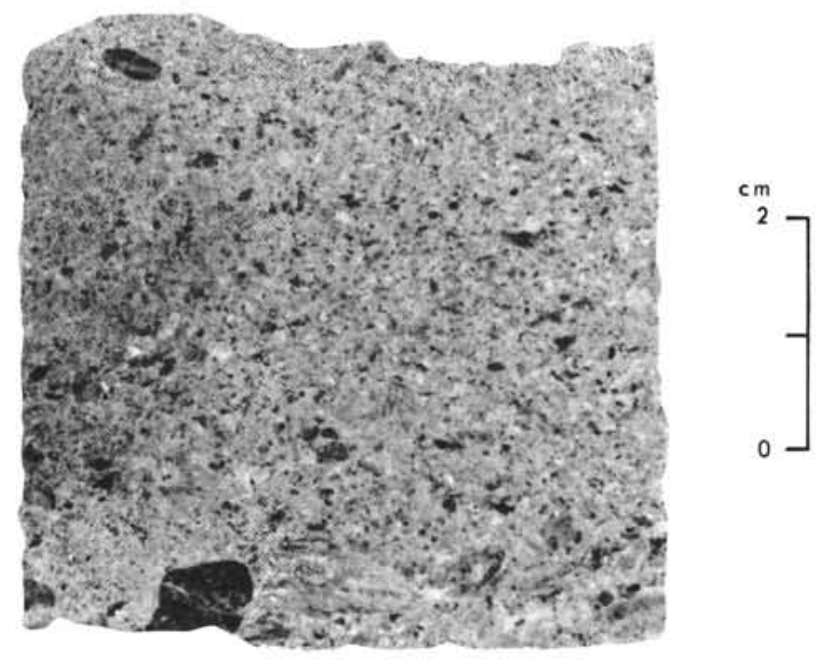

Figure 8. Unusually thick sandy interval in breccia deposit, Core 45, Site 270, at a subbottom depth of 396.5 meters. Shows gradation into breccia at base. General color of core is pale olive. include biotite gneiss, hornblende gneiss, biotite schist, hornblende schist, hornfels, jasperoidal rock, pegmatite, and marble. Garnet is a common constituent of leucogneiss. The dominant lithologies are marble and calc-silicate gneiss, followed by leucogneiss and leucogranite. The calcareous rocks are scattered throughout the core but seem to be especially dominant in lower parts. They are closely similar to basement rocks described above.

\section{Petrography}

Thin-section study of five samples of breccia shows that even at a microscopic scale the rock has a chaotic, unsorted appearance like that in hand specimen. Welldefined grain fabric was not seen, though local areas a few millimeters across seem to show weak grain orientation. The matrix is an unsorted, generally fine to coarse, gritty sand, with no single predominating size. Minor silt is seen, but if much silt and any clay are present they are obscured by the extensive carbonate cement, probably calcite, which fills all intergrain areas. The carbonate, which is slightly cloudy and locally twinned, forms crystals typically between 0.5 and $1 \mathrm{~mm}$ across. A few crystals reach $4 \mathrm{~mm}$ across and appear partly or completely to enclose lithic and crystal clasts. Many sand grains show signs of replacement by calcite; plagioclase grains, in particular, have been replaced and some show only a few isolated patches of original material. Quartz grains are also affected, as evidenced by the common "scalloped" margins showing gently curved embayments up to $0.2 \mathrm{~mm}$ deep. In samples from the lower part of the breccia, calcite fills only from $30 \%$ to $50 \%$ of intergrain areas, and the dominant filling material is a low-birefringent, microcrystalline $(\sim 2-5 \mu)$, pale green material, probably a chloritic clay.

Quartz is the dominant grain type in the sand-size fraction of the breccia; most grains larger than about 0.2 $\mathrm{mm}$ are composite, being quartzite fragments that show intricately sutured crystal boundaries. Isolated quartz grains and crystals in quartzite commonly show strong wavy extinction. Feldspar grains are about one-half as abundant as quartz; K-feldspar, commonly showing incipient grid twinning, is generally fresh; plagioclase is generally cloudy, showing alteration to sericite and clay. Greenish to brownish detrital biotite, partly altered to chlorite, is locally abundant in the breccia matrix. Rare grains of detrital muscovite, tourmaline, apatite, sphene, and an epidote-group mineral, possibly zoisite, are also present. The detrital tourmaline is yellowish-brown to bluish-gray, strongly pleochroic, and of similar appearance to that in lithic clasts of tourmaline granite, from which it is probably derived. Sand-size lithic clasts appear to be about as abundant as feldspar crystal clasts, many are highly altered, and some are difficult to distinguish from patches of chloritic matrix material. Lithologies of lithic sand grains include the quartzite mentioned above, probable pegmatite, well-foliated chlorite-biotite-calcite-quartz schist, quartz-plagioclase granofels, calc-silicate rock, and finely crystalline chloritic schist. Sand-size clasts of marble are probably present, but cannot be distinguished from coarsely crystalline calcite cement. 
Lithologies of granule-size and larger lithic clasts, as identified microscopically, include, in addition to the above, tourmaline-muscovite granite, sheared augentextured quartz-feldspar granofels containing tourmaline, foliated metagraywacke, muscovite-bearing quartzite, coarse pegmatite, and marble, some of which is coarsely crystalline or highly sheared and showing bent twin lamellae and a thinly lenticular, wavy cataclasite structure. The tourmaline-bearing rocks form large clasts up to cobble size in Core 44, Section 5.

The principal postdepositional changes in the breccia were cementation, by pore-space filling with calcite and (or) by recrystallization of matrix material, and alteration that may in part be related to cementation. Introduction or redistribution of carbonate is indicated by the common thin film of crystalline calcite, from 0.1 to $0.2 \mathrm{~mm}$ thick, partly or completely rimming many large clasts, and by the numerous veinlets of calcite cutting the matrix and locally extending into interiors of lithic clasts. A few clasts have an "exploded" appearance, showing fragments supported in a sea of calcite. Textural relations suggest partial replacement of plagioclase by calcite is postdepositional. Much of the chloritization of detrital biotite, particularly in the regolith, resulted from weathering. In lower parts of the deposit pore spaces are filled by calcite and microcrystalline chloritic clay. Patches of low-birefringent material, possibly zeolite, in the matrix are also postdepositional. Many lithic fragments show evidence of cataclasis, but in most, the shear planes are entirely internal indicating that deformation occurred prior to deposition, apparently within the source terrane. However, at two places, one in Sample 44, CC, and the other in Core 47, Section 2, shear planes a few millimeters wide cut the breccia matrix and have disrupted detrital grains and lithic clasts, indicating that at least minor postdepositional deformation has occurred.

\section{Provenance and Origin}

The abundant fragments of marble and calc-silicate rock in the breccia are obviously derived from local basement terrane such as sampled at the base of the drill hole. Clast lithologies indicate that the source region is a widely varied metamorphic and granitic terrane similar to basement rocks exposed in southern Victoria Land (Warren, 1969; Blank et al., 1963; Williams et al., 1971) and in Marie Byrd Land (Wade, 1969; Klimov, 1968). Metamorphic-mineral assemblages in both regions include those of the amphibolite facies (Lopatin, 1972; Klimov, 1968), which is also indicated by diopside in calc-silicate gneiss at Site 270. The apparent absence in the breccia of metavolcanic lithologies similar to those of Marie Byrd Land, and the abundance of calcareous metasedimentary rocks similar to those near McMurdo Sound, but not reported in Marine Byrd Land, indicate that the source terrane is more like that of southern Victoria Land than of Marie Byrd Land.

The origin of the breccia is uncertain. Any hypothesis must explain features such as angularity and poor sorting of clasts, apparent lack of significant amounts of silt and clay, vague alternation of subhorizontal and dipping layers, wide range in lithology of clasts of all sizes, abundance of pore space if carbonate cement was introduced, lack of clearly defined contact with basement rocks, and relative abundance of fragments having lithologies of those of known basement rocks in the core. The materials were neither carried any great distance nor deposited by running water. Glacial transport and deposition seems equally unlikely. The most likely mechanisms of origin are talus deposition near the base of a cliff, or accumulation of solifluction materials below a slope. Either mechanism can account for the above characteristics. Alternatively, a catastrophic origin by some type of cryptovolcanic explosion or impact might account for these features as well as for the common cataclastic appearance of the rocks.

\section{SUMMARY AND CONCLUSIONS}

Basement materials sampled at Site 270 in the southcentral Ross Sea are calcareous metasedimentary rocks of the amphibolite facies that have been retrogressively metamorphosed in the greenschist and probably zeolite facies. The metamorphic basement rocks are overlain by sedimentary breccia, about 25 meters thick, composed of poorly sorted granitic and metamorphic fragments in chaotic array. These materials probably accumulated in - talus deposit or by solifluction from a nearby topographic high of basement terrane. This source terrane is generally similar to that of basement-rock regions of southern Victoria Land, and the calcareous metasedimentary rocks may correlate with similar rocks of the early Paleozoic(?) Skelton Group near McMurdo Sound. The lack in the breccia of fragments of diabase, basalt, and gabbro, such as in the Jurassic Ferrar Dolerite intrusive and extrusive bodies in Victoria Land, and of sandstone and siltstone, such as common in the Devonian to Jurassic Beacon Supergroup in the same area, indicates that these widespread units did not extend to this region at the time of breccia deposition.

The finding of continental-type basement rocks in the central Ross Sea was a highly signiticant result of drilling at Site 270. It indicates that at least the site region is not a graben depression filled by Beacon sediments as has been proposed for regions near McMurdo Sound (Taylor, 1930); and that it is not a rift depression filled with volcanic materials. Moreover, if late Precambrian metagraywacke terranes of northern Victoria Land extend across Ross Sea to Marie Byrd Land, as has been proposed, this connection must lie to the north of the drill site.

The regolith formed on the breccia is believed to be subaerial, and suggests a relative rise in sea level, or crustal depression, of at least 1000 meters at Site 270 since it developed probably in early Tertiary time.

\section{ACKNOWLEDGMENTS}

We gratefully acknowledge the abundant shipboard help of all fellow participants on Leg 28 of Glomar Challenger, and manuscript reviews by Béla Csejtey, Jr., and R.G. Yates.

\section{REFERENCES}

Blank, H.R., Cooper, R.A., Wheeler, R.H., and Willis, I.A.G., 1963. Geology of the Koettlitz-Blue Glacier region, southern Victoria Land, Antarctica: Roy. Soc. New Zealand Trans., v. 2, p. 791. 
Houtz, R. and Davey, F.J., 1973. Seismic profiler and sonobuoy measurements in Ross Sea, Antarctica: J. Geophys. Res., v. 78 , no. 17 , p. 3448 .

Klimov, L.V., 1968. Some results of geological investigations in Marie Byrd Land in 1966-1967: Information Bull., Soviet Antarctic Expedition (in English), p. 555.

Laughton, A.S., Berggren, W.A., et al., 1972. Explanatory notes, In Laughton, A.S., et al., Initial Reports of the.Deep Sea Drilling Project, Volume 12: Washington (U.S. Government Printing Office).

Lopatin, B.G., 1972. Basement complex of the McMurdo "Oasis", south Victoria Land. In Adie, R.J.(Ed.), Antarctic geology and geophysics: Oslo (Universitetsforlaget), p. 287.
Taylor, G., 1930. Antarctic adventure and research: New York (D. Appleton and Co.).

Turner, F.J., 1968. Metamorphic petrology: New York (McGraw-Hill).

Wade, F.A., 1969. Geology of Marie Byrd Land, sheet 18, Geologic Maps of Antarctica: New York (Am. Geogr. Soc.).

Warren, G., 1969. Geology of the Terra Nova Bay-McMurdo Sound area, Victoria Land, sheet 14, Geologic Maps of Antarctica: New York (Am. Geogr. Soc.).

Williams, P.F., Hobbs, B.E., Vernon, R.H., and Anderson, D.E., 1971. The structural and metamorphic geology of basement rocks in the McMurdo Sound area, Antarctica: J. Geol. Soc. Australia, v. 18, p. 127. 